\title{
CREATION OF A MAP OF PALEOZOIC BEDROCK SPRINGSHEDS IN SOUTHEAST MINNESOTA
}

Jeffrey A. Green

Minnesota Department of Natural Resources, Division of Ecological \& Water Resources, 3555 9th St. NW Suite 350,

Rochester, MN, U.S.A., 55904, jeff.green@state.mn.us

E. Calvin Alexander, Jr.

Morse-Alumni Professor Emeritus, Earth Sciences Department, University of Minnesota, 310 Pillsbury Dr. SE,

Minneapolis, MN 55455,alexa001@umn.edu

\section{Abstract}

Springs are groundwater discharge points that serve as vital coldwater sources for streams in southeast Minnesota. The springs generally emanate from Paleozoic carbonate and siliciclastic bedrock aquifers. Use of systematic dye tracing began in the 1970s and continues through the present as a standard method for investigating karst hydrology and to map springsheds. The work was accelerated in 2007 because of increased funding from the State of Minnesota's Environment and Natural Resources Trust Fund. A compilation springshed map of dye traces conducted over the last several decades has been assembled for the region.

In southeast Minnesota, the springs are the outlets of conduit flow systems in both carbonate and siliciclastic bedrock aquifers. Conduit flow dominates groundwater transport in carbonate aquifers and is an important component of groundwater flow in siliciclastic aquifers. Conduit flow in aquifers occurs independently of the presence or absence of surface karst features.

The springsheds of these springs have three interacting components: Groundwater Springsheds (analogous to classic karst autogenic recharge areas), Surface Water Springsheds (analogous to classic karst allogenic surface runoff areas), and Regional Groundwater Springsheds.

Surface Water Springsheds can be up to several orders-ofmagnitude larger than the Groundwater Springsheds to which they contribute water. Surface Water Springsheds can feed surface flow into one or several stream sinks. Those multiple stream sinks may be in one or more Groundwater Springsheds.

The leading edges of dye tracing breakthrough curves typically show groundwater flow velocities in the hundreds-of-meters to kilometers-per-day range in all of the bedrock aquifers tested. The width and duration of tails of breakthrough curves in these conduit flow systems vary with the bedrock aquifers. The Galena Group has Full Widths at Half Maximums (FWHMs) of a few hours and tails that are down to background in a few days. The Prairie du Chien Group also has FWHMs of hours but has tails that continue for weeks. The St. Lawrence and Lone Rock Formations have FWHMs of months to years.

\section{Introduction}

Springs are natural discharge points for groundwater systems. They provide baseflow for streams and are critical sources of cold, relatively constant-temperature water for trout streams. In southeast Minnesota (Figure 1) springs are commonly found emerging from the Paleozoic sedimentary rocks where river valleys deeply incise the water-bearing bedrock layers. In this region, many springs flow from carbonate (limestone, dolostone) and carbonate-cemented siliciclastic layers. These formations dissolve in slightly acidic groundwater and have developed integrated systems of conduits that allow groundwater to flow quickly through the aquifers

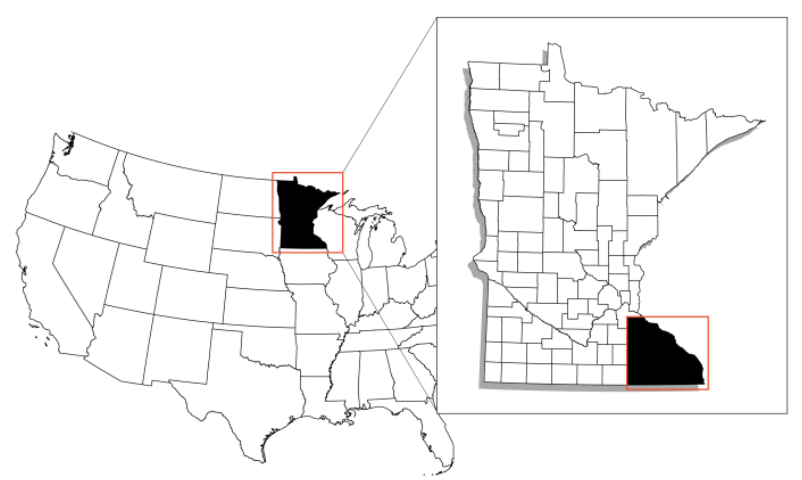

Figure 1. Location map of the state of Minnesota. The study area is indicated by black shading in the inset. 
and emerge in the springs. Many other springs emerge from siliciclastic units which contain no significant carbonates. Springs emanating from siliciclastic bedrock aquifers share some of the key hydrologic properties while not exhibiting all of the characteristics of traditional carbonate karst.

In order to conserve and protect springs and the surface water bodies they supply, it is necessary to understand the geologic setting and from where the water is derived. The University of Minnesota ( $U$ of $M$ ), the Minnesota Department of Natural Resources (DNR), and a group of experienced local cavers have been mapping springsheds in southeast Minnesota since the 1970s. The working hypothesis of these groups is that dye traces provide fundamentally valuable scientific information about how groundwater moves in the subsurface. This can ultimately provide a better understanding of these systems, which is needed to formulate public policies and guide professional decisions. Funding from the State of Minnesota Environment and Natural Resources Trust Fund (ENRTF) has allowed these researchers to accelerate and formalize efforts to delineate springsheds by releasing fluorescent organic dyes into sinkholes or sinking streams to determine the general flow paths to springs. This information was assembled to produce a new map, "Mapped Paleozoic Bedrock Springsheds in Southeast Minnesota" (Green and Alexander, 2014). This map displays the springsheds which were mapped and verified as of June 2014 at a 1:150,000 scale. It also incorporates work done as part of the Fillmore County Geologic Atlas (Alexander et al., 1996). Green et al. (2014) presented the methodology used to define springsheds shown on the map. This paper discusses some of the results of that effort.

A springshed can be defined as "those areas within ground- and surface-water basins that contribute to the discharge of a spring" (Copeland, 2003). Dye tracing is the preferred method for documenting karst springsheds. Kingston (1943) reported the earliest known dye traces in Minnesota karst, which were conducted in 1941 in response to a typhoid fever outbreak in 1940 in Harmony, Fillmore County, Minnesota. When coauthor E. Calvin Alexander, Jr. began tracer studies in Fillmore County in the late 1970s, the theoretical model was that of the classic autogenic and allogenic recharge components to karst water systems. This model was reasonable in the well-developed Galena karst of Fillmore County, but there were caveats. Within the county, there are allogenic areas where perennial surface streams flow and then sink to become sinking streams, but they are either: 1) perched on patches of relatively impermeable glacial deposits on top of the Paleozoic carbonates and sandstones; 2) in areas where relatively impermeable shale is the first bedrock; or 3 ) in areas where the first water table is at or near the surface. There are autogenic areas where surface water flows only for short times after major precipitation events or spring snow melts, and allogenic flows that sink in sinking streams or sinkholes. But in these areas most of the recharge was found to be through the thin soils rather than into sinkholes or sinking streams (e.g., Hallberg et al., 1984). Large areas exist over shallow carbonate bedrock with no perennial surface water flow, but where there are few if any visible surface karst features. Inappropriate projects proposed for such areas prompted innumerable, incredibly unproductive debates and negotiations over how many sinkholes are necessary in a given area to define it as a "karst".

As we expanded dye tracing work into adjoining counties east and north of Fillmore County in stratigraphically lower carbonates, sandstones and siliciclastic rocks, the allogenic and autogenic models became increasingly untenable. In addition, a third major component of spring flows became more apparent. The Paleozoic aquifers extend westward far beyond the extent of the allogenic and autogenic basins. Regional groundwater from these areas was shown to contain increasingly larger components of flow from the stratigraphically lower springs.

In Green and Alexander (2014) and Green et al. (2014) our conceptual model is described to include three sources of spring flow, i.e., three (at least conceptually) mappable components to each springshed. These three components are shown diagrammatically in Figure 2.

Groundwater Springsheds (GwS): Areas where precipitation infiltrates from the land surface to the first conduit-flow dominated aquifer and flows to the spring. GwSs are mapped mainly based on groundwater flow connections demonstrated by tracing techniques. These flow velocities are much faster than typically expected based on porous media models. Our GwS can include classic autogenic basins in addition to areas that don't fit various definitions of autogenic basins. 


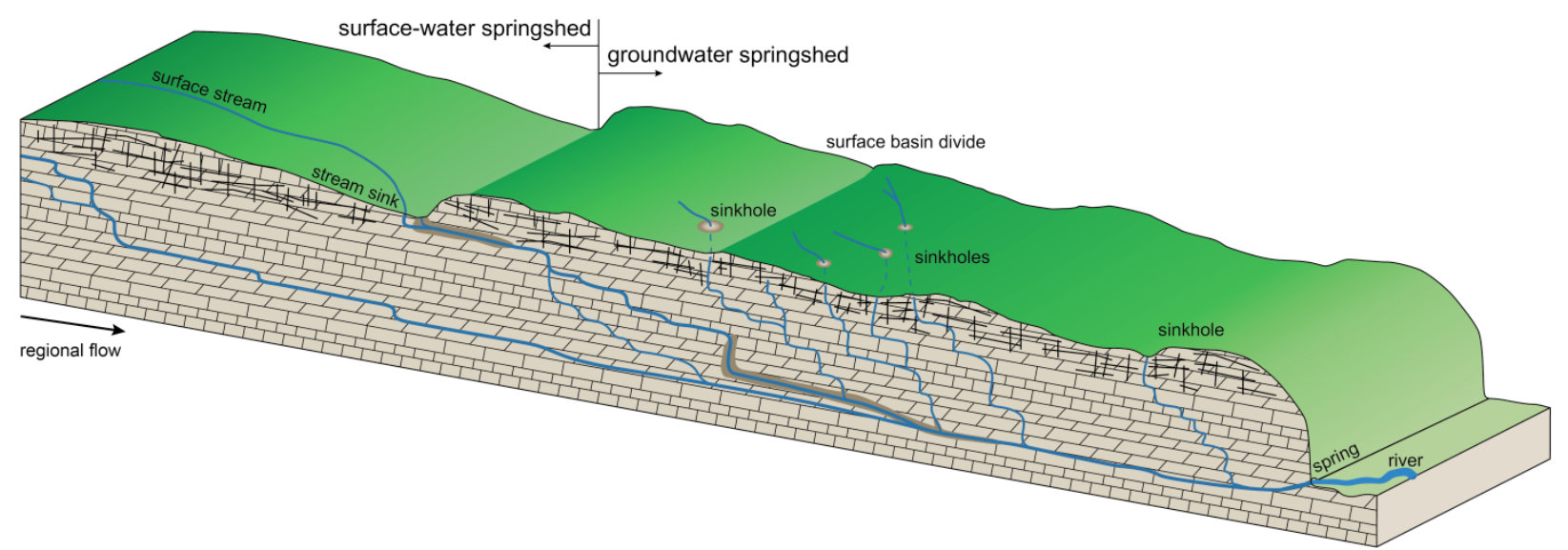

Figure 2. Springshed block diagram. A surface water springshed is the watershed of a perennial or intermittent stream flowing across the land surface that descends into stream sinks or sinkholes. Those sinking points mark the beginning of a groundwater springshed carrying groundwater flow to a downgradient spring. The black lines represent the general direction of groundwater flow through enlarged openings in the subsurface, such as vertical and horizontal joints and fractures. The blue lines depict flow from sinkholes and stream sinks. The gray-shaded linear features along two of the blue lines represent larger conduits carrying groundwater flow. Regional groundwater springshed flow (shown as regional flow in the diagram) is a third component of the flow of a spring. Water enters the groundwater system by way of continued infiltration from the surface and can come from areas under or far beyond the surface water springsheds. Regional sources of water to a spring have a significantly longer underground residence time and can provide a large fraction of spring discharge.

Surface Water Springsheds (SWS): Areas where water flows across the land surface in perennial streams (streams that typically flow all year, perhaps except under unusually dry conditions) before sinking into the subsurface at the edges of GwSs. These areas include, but are not limited to, classic allogenic basins and are mappable using conventional surface topography maps and digital elevation models coupled with field work to identify sinking streams.

Regional Groundwater Springsheds (RGS): Areas contributing to a spring's flow that are beyond or underneath the GwSs and the SWSs. Given the regional extent of these Paleozoic aquifers in Minnesota, the RGSs can extend many kilometers to the west. These RGSs can be a major source of the flow to a spring. Conceptually they can be mapped from sufficiently detailed regional potentiometric maps, but such maps rarely exist in this region. The volumetric contribution of flow to a spring from RGSs can be recognized and sometimes estimated from geochemical and isotopic water quality data, even if the geographic extent of the RGS is unknown (e.g., Runkel et al., 2014).
The boundaries of these three types of springsheds do not necessarily correspond to those of overlying surface watersheds. In addition, the groundwater springshed boundaries are dynamic, changing as groundwater levels rise and fall, in response to wetter and drier cycles of precipitation.

\section{Hydrostratigraphic Background}

The flat-lying Paleozoic sedimentary bedrock of southeast Minnesota is Cambrian to Devonian in age (Mossler, 2008) and was deposited as a series of shallow, fluctuating seas advanced and retreated across what is now southeast Minnesota (Figure 3). The Cambrianage rocks are primarily sandstone, siltstone and shale while the Ordovician and Devonian rocks are primarily carbonate (limestone and dolostone) and shale.

Bedrock layers that serve as the source of water for the many springs found in southeast Minnesota are displayed on the stratigraphic column (Figure 3), The Decorah Shale (dark blue-gray in Figure 4 and 5) is a regional aquitard and is the boundary between the Galena limestone karst system and the Prairie du Chien karst system (Runkel et al., 2014). Many springs discharge 


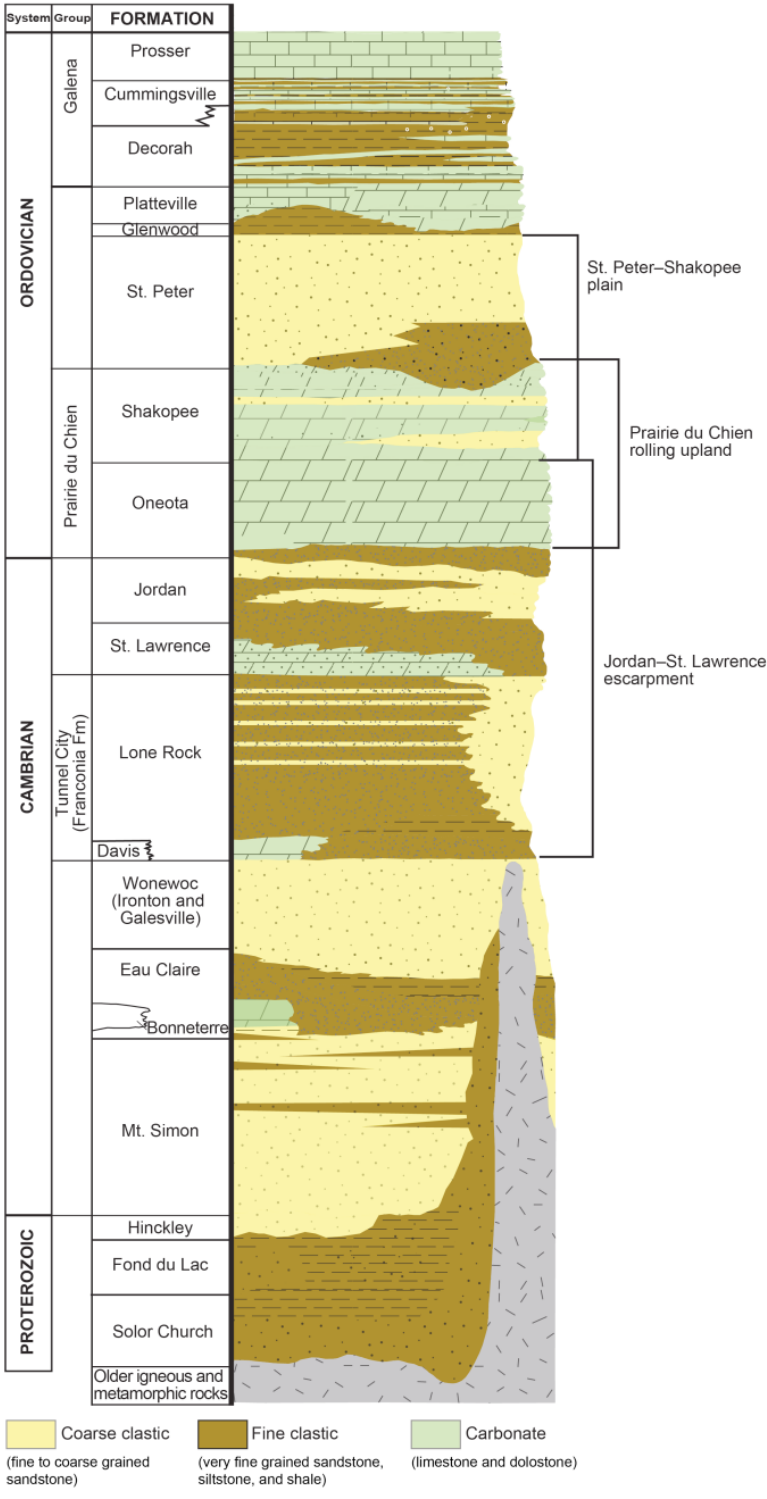

Figure 3. Stratigraphic column. This stratigraphic column shows the bedrock of southeast Minnesota, highlighting lithostratigraphic attributes (crystalline basement rock shown in hachured grey). The carbonate bedrock has been partially dissolved to form karst aquifers. The coarse clastic bedrock stores and transmits large volumes of water in the primary pore space in the sandstone matrix. The Decorah formation has a low primary permeability that does not allow water to infiltrate readily. Therefore, water is forced to flow laterally to numerous springs at or near its upper contact. The St. Lawrence formation has enhanced secondary porosity and permeability in the form of bedding plane fractures and conduits, which is a critical factor for spring occurrence. Adapted from Mossler (2008). from the lower Galena because the water cannot move through the relatively impervious, underlying Decorah shale. The St. Lawrence Formation (green in Figure 6) is an important regional bedrock unit from which many springs discharge and where disappearing streams (stream sinks) contribute water to springs (Green et al., 2008; Green et al., 2012).

These rock units are covered by varying thicknesses of regolith (mixtures of tills, outwash deposits and loess). Areas with less than 15 meters of regolith have been the focus of springshed mapping efforts because sinkholes and disappearing streams are primarily found in those areas. Surface karst features are not common where the regolith is thicker than 15 meters (brown areas in Figures 4,5 , and 6). The areas where the thickness of regolith is greater than 15 meters are typically in three settings: isolated areas in the blufflands regions, alluvium deposits along major rivers, and under deep glacial deposits to the west.

The hydrostratigraphy of southeastern Minnesota is further complicated by the extensive development of subvertical joints and fractures, subhorizontal bedding plane parallel fractures, and subtle structural features (Runkel et al., 2014). In addition, Alexander et al. (2013) have emphasized the role that the numerous, long, subaerial unconformities in this section have played in the development of the extensive, pervasive secondary porosity and permeability in these rocks.

\section{Methods}

The GwSs were defined primarily from sinking stream or sinkhole to spring connections established by tracing techniques. Tracing technology and techniques have evolved significantly from the late 1970s to the present. Tracing agents have included cations, anions, conductivity, environmental stable and radioactive isotopes, injected stable isotopes, lycopodium spores, heat, flow pulses and sediments. The bulk of the tracing work, however, has used fluorescent dyes as the tracers. Several water tracing fluorescent dyes have been used, but our standard dyes were Rhodamine WT, sulforhodamine B, eosin and fluorescein/Uranine.

Initial fluorescent dye traces in the 1970s were conducted using visual dye detection. In the 1980s and early 1990s, Turner Designs Model 10-005 Field Filter Fluorometers Fluorometers were used to analyze the 
water and bug samples. In 1993 a Shimadzu RF5000U Scanning Spectrofluorophotometer became our standard dye analysis instrument and that continues to be used at the present (Alexander, 2005).

The dye traces have used a mixture of sample collection methods, such as integrating charcoal detectors (bugs) and direct water samples. The major technological change in direct water sampling was the availability of auto-sampling devices for timed direct water sampling, starting in the 1980s. Both direct water sample and bug trace techniques are still used.

Multiple dyes have been used since the 1990s to trace from different sinkholes or stream sinks at the same time. The dyes were introduced into the groundwater systems through sinking streams, snow melt running into sinkholes, and dry sinkholes. In the latter case, the dyes were flushed with water from a tanker truck (typically 1800-7500 liters). Successful dye traces were conducted in the Lithograph City Formation, Spillville Formation, Galena Group, Prairie du Chien Group, St. Lawrence Formation, and the Lone Rock Formation (Figure 3).

The SWSs were mapped topographically where they contribute surface runoff to a mapped stream sink. The upstream boundaries of surface water basins were identified using watershed maps derived from digital elevation models (DEM) created with Light Detection and Ranging (LiDAR) data or topographic maps (Minnesota Department of Natural Resources, 2014). The catchment area upstream of the stream sink was identified using an ArcGIS tool that selects the surface watersheds upstream of a given point.

\section{Results}

The Green et al. (2014) map displays GwSs and SWSs identified across southeast Minnesota. The GwS boundaries are outlined in red and record conditions at the time that the dye traces were conducted. SWSs are outlined in yellow. Common boundaries of neighboring springsheds represent surfacewater or groundwater divides. Sinkholes or stream sinks that were used as dye-trace input points are symbolized differently depending on whether or not dye was later detected in the springs that were being monitored. The dye-trace vectors (black arrows) are the diagrammatic depiction of the groundwater flow routes.

\section{Galena Group Springsheds}

Figure 4 is reproduced from Inset 2, an enlarged portion of the Green and Alexander (2014) map showing GwSs and SWSs in the well-developed Galena Group karst of west central Fillmore County. More dye traces have been conducted in the Galena than in all of the other bedrock units combined. Mohring and Alexander (1986) summarized the early dye traces in this area. Many additional traces were included in the Alexander et al.(1996) map which was a precursor of the Green and Alexander (2014) map. Luhmann et al. (2012) report multi-tracer experiments in the area shown in Figure 4. Many, but not all, of the flow vectors in Figure 4 enter the subsurface at sinking streams or sinkholes in the Dubuque and Stewartville Formations and their spring resurgences are in the lower Cummingsville Formation above the Decorah Shale.

The Stewartville and Prosser formations of the Galena Group exhibit the densest sinkhole development in Minnesota. Groundwater flow through these units is dominantly through conduits, solution-enlarged joints, and fractures. Groundwater flow paths from sinkholes and stream sinks to springs in the Galena Group often cross surface watershed boundaries. The low permeability of the rock matrix generally provides negligible flow. Multiple dye-tracing investigations have demonstrated breakthrough travel velocities of 1.6 to $4.8 \mathrm{~km}$ per day (Green et al., 2005).

Tracer breakthrough curves through the Galena Group are only slightly asymmetric with small, exponentially decreasing tails. The breakthrough curves typically have Full Widths at Half Maximums (FWHM=the time duration of the breakthrough curve measured between the points on the concentration axis which are at half of the maximum concentration) of a few hours; the tails are often back to background levels in a few days.

Dye traces from sinkholes and stream sinks on the boundaries of multiple groundwater springsheds have demonstrated that those boundaries are dynamic: groundwater flow directions can change in response to recharge events. The springsheds vary greatly in size ranging from several hundred hectares to many square kilometers (Green et al., 2005), have thin glacial cover over bedrock, and commonly have sinkholes. Stream sinks and sinkholes serve as direct recharge points for surface water to enter the limestone aquifer and are good 


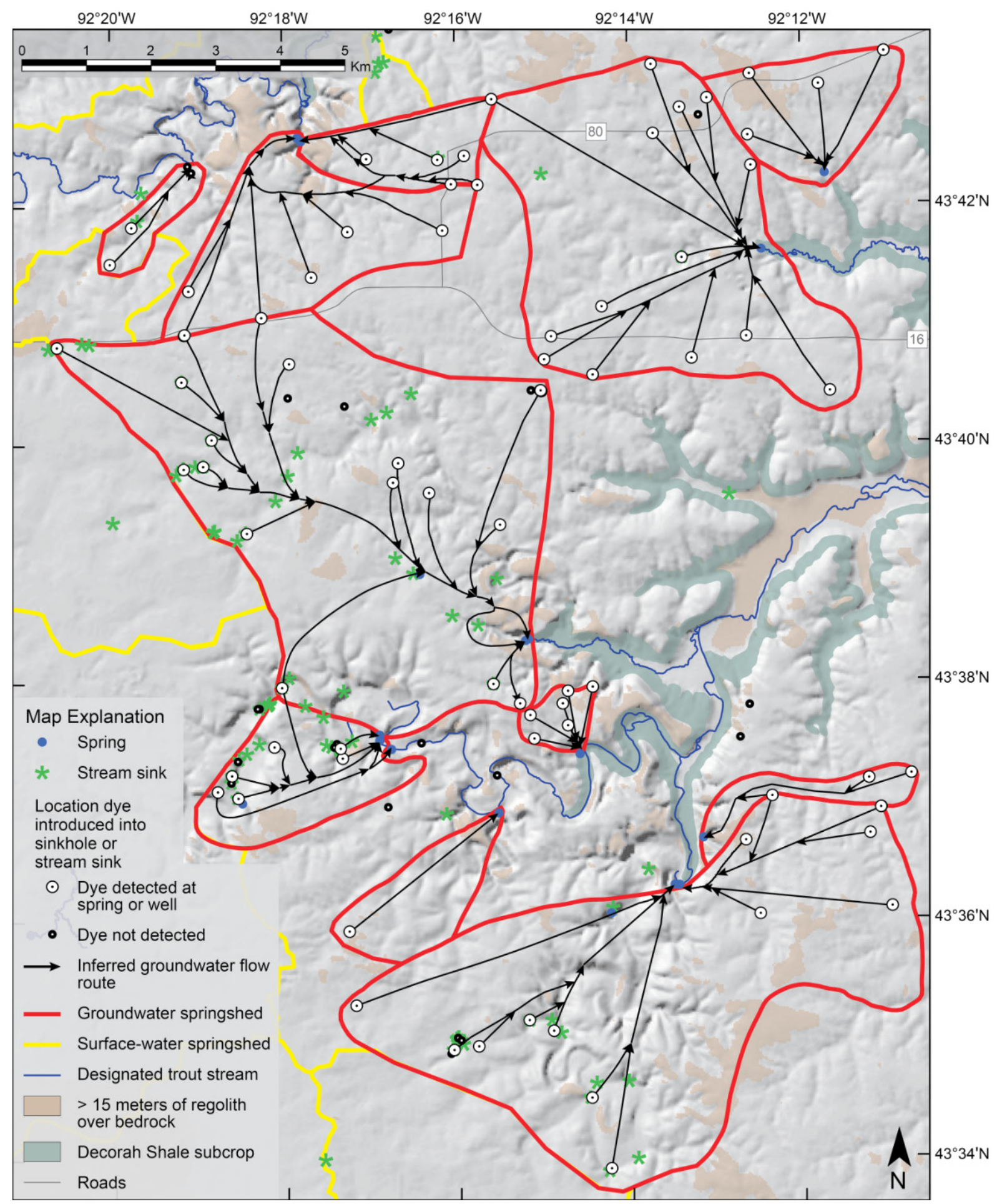

Figure 4. Map of springsheds in the Galena Group limestone karst. (Inset 2 from Green and Alexander, 2014). The inferred groundwater flow route vectors are diagrammatic depictions of the connections discovered by dye tracing from a dye introduction point (sinkhole or stream sink) to a spring. The dye traces are used to delineate the boundaries of Groundwater Springsheds. While most of the sinkholes and stream sinks transmit water to a single spring, there are several that connect to multiple springs in different directions. These traces mark the boundaries between Groundwater Springsheds under the hydrologic conditions at the time of the dye trace. 
indicators of conduit flow in the subsurface. Recharge water also infiltrates through the sediment cover and into the carbonate bedrock. The landscapes between the sinkholes or stream sinks and the springs to which they are connected may lack surface-karst features but are characterized by high velocity conduit flow in the subsurface.

\section{Prairie du Chien Group Springsheds}

Figure 5 is an enlarged portion of the Green and Alexander (2014) map showing the Prairie du Chien Group GwS and SWSs of the West Branch of Duschee Creek Valley in east central Fillmore County, Minnesota. The Prairie du Chien Group is stratigraphically lower than the Galena Group, and is the first bedrock in a broad band stretching east and north of the Galena Group subcrop. It extends from the Iowa border northwestward and underlies much of the Twin Cities Metropolitan Area at a relatively shallow depth. The stratigraphically intervening Platteville, Glenwood and St. Peter Formations tend to be present as the first bedrock in only narrow bands which are not extensive at the surface. Typically they are primarily seen along incised stream valleys where a portion of the Galena Group remains as a cap rock.

The Prairie du Chien Group is a major aquifer across much of southeast Minnesota. The visible surface karst features are sparse and are typically further apart than in the Galena karst; large portions of the Prairie du Chien subcrop have little if any perennial surface water flow and groundwater contamination issues are widely present. Alexander et al. (2013) describe the karst conditions that led to the catastrophic sinkhole collapse of three Municipal Waste Water Treatment Lagoons on the Prairie du Chien.

The Duschee Creek Valley area in Figure 5 is of interest because the two large springs at the north end of the valley are the water sources of the Lanesboro State Fish Hatchery, which produces brown and rainbow trout for stocking programs in Minnesota. Thus, these springs provide the water source for an enormously important statewide economic resource.

Dye traces from a large sinkhole $3.4 \mathrm{~km}$ south southeast of the Hatchery Spring demonstrated rapid breakthroughs (flow velocity of several $\mathrm{km} /$ day) at the Hatchery Springs with FWHMs of hours to a day. But the tails of the breakthrough curves extended for weeks (Wheeler, 1983). This pattern is one of four flow patterns we have observed in traces in the Prairie du Chien Group and is the most common pattern in this hydrologic system.

In 1991, co-author Jeff Green located a critical stream sink in the West Branch of Duschee Creek Valley, 3.7 $\mathrm{km}$ south of the Hatchery Spring. Dye traces in 1991 and 1992 documented that the stream sink was a major source of storm water contaminants to the Hatchery Springs. An engineered sealing of that stream sink and rerouting of the stream away from the stream sink eliminated the storm water contamination at the Hatchery Spring (Kalmes and Mohring, 1995).

A second pattern was observed in a 1984 well-to-well trace in the Shakopee Formation of the Prairie du Chien Group (Alexander and Milske, 1986). A breakthrough flow velocity of approximately $2 \mathrm{~km} /$ year was observed with a broad, smooth peak persisting about two months, followed a second two-month smaller peak.

A third pattern was observed in dye traces conducted at the Oronoco Landfill in Olmsted County (Alexander et al., 1991). We observed an initial rapid breakthrough spike at monitoring wells, followed by an exponential drop off with a half-life of a few days. The initial spike was followed by a series of precipitation-driven, decreasing spikes over the next couple of years.

The fourth "pattern" is no pattern. About 15 percent of the dye traces attempted in the Prairie du Chien were never detected at any monitoring point (Green and Alexander, 2011).

\section{St. Lawrence and Lone Rock Formation Springsheds}

Figure 6 is reproduced from Inset 4, an enlarged portion of the Green and Alexander (2014) map showing the three adjacent GwSs and SWSs mapped to date in eastern Fillmore and western Houston Counties, Minnesota.

Groundwater flow through the St. Lawrence is through conduits that include modified bedding-parallel fractures, nonsystematic vertical fractures, and through the bedrock matrix (Runkel et al., 2003). Dye tracing has shown that, while not exhibiting all of the characteristics of traditional carbonate karst, the St. Lawrence Formation has a karst-like conduit flow component. Multiple dye- 


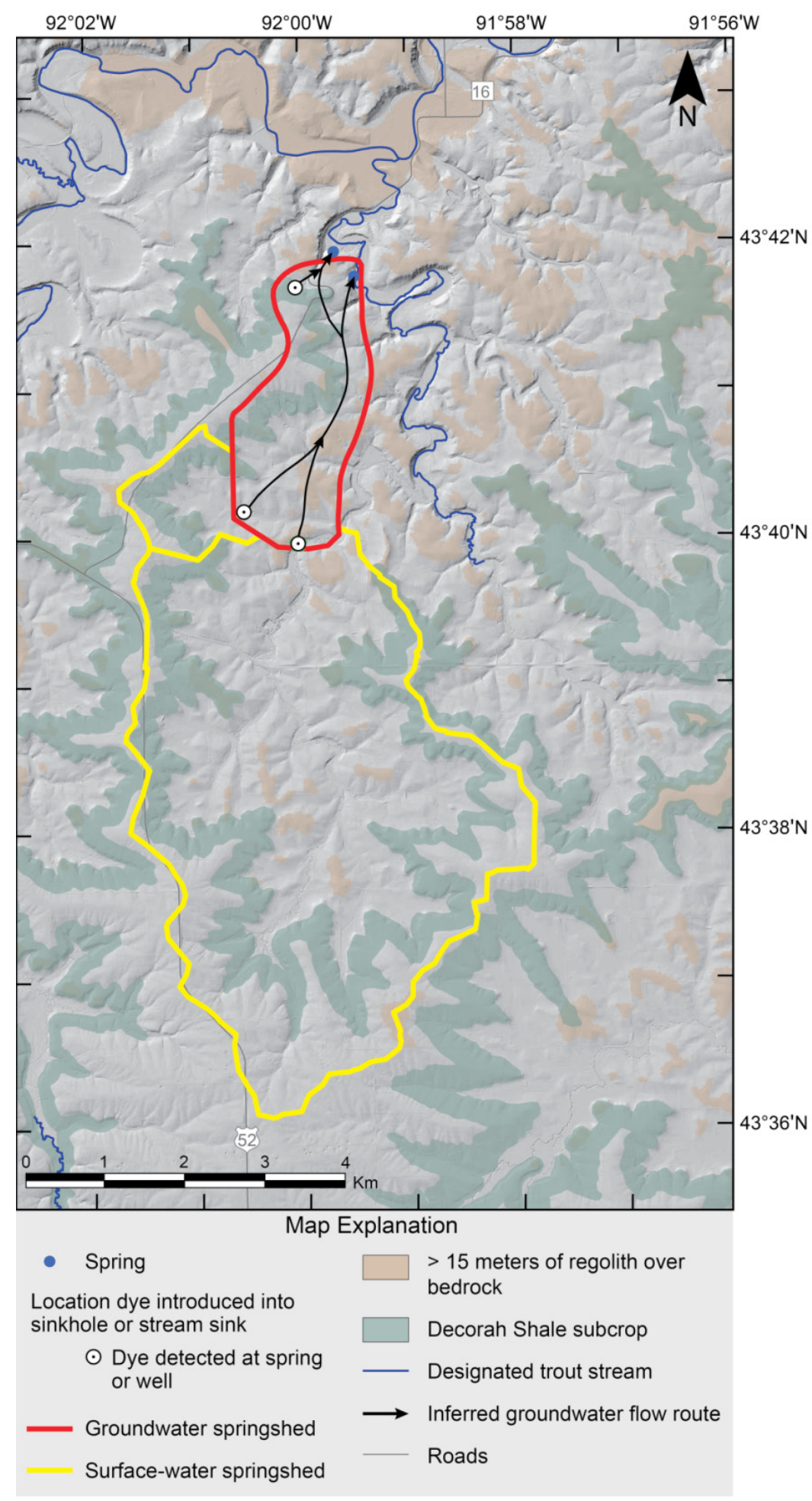

Figure 5. Map of Springsheds in the Prairie du Chien Group carbonate karst. An enlarged section of Green and Alexander (2014). This figure shows the GWS and SWSs of the two large springs that are the water sources of the Lanesboro State Fish Hatchery. The two southern dye input points (a sinkhole and a stream sink) have been shown by dye tracing to be connected to both springs. The northernmost dye point is a well that had dye introduced below the surface in the annulus prior to grouting. That dye was only detected at the west spring. 


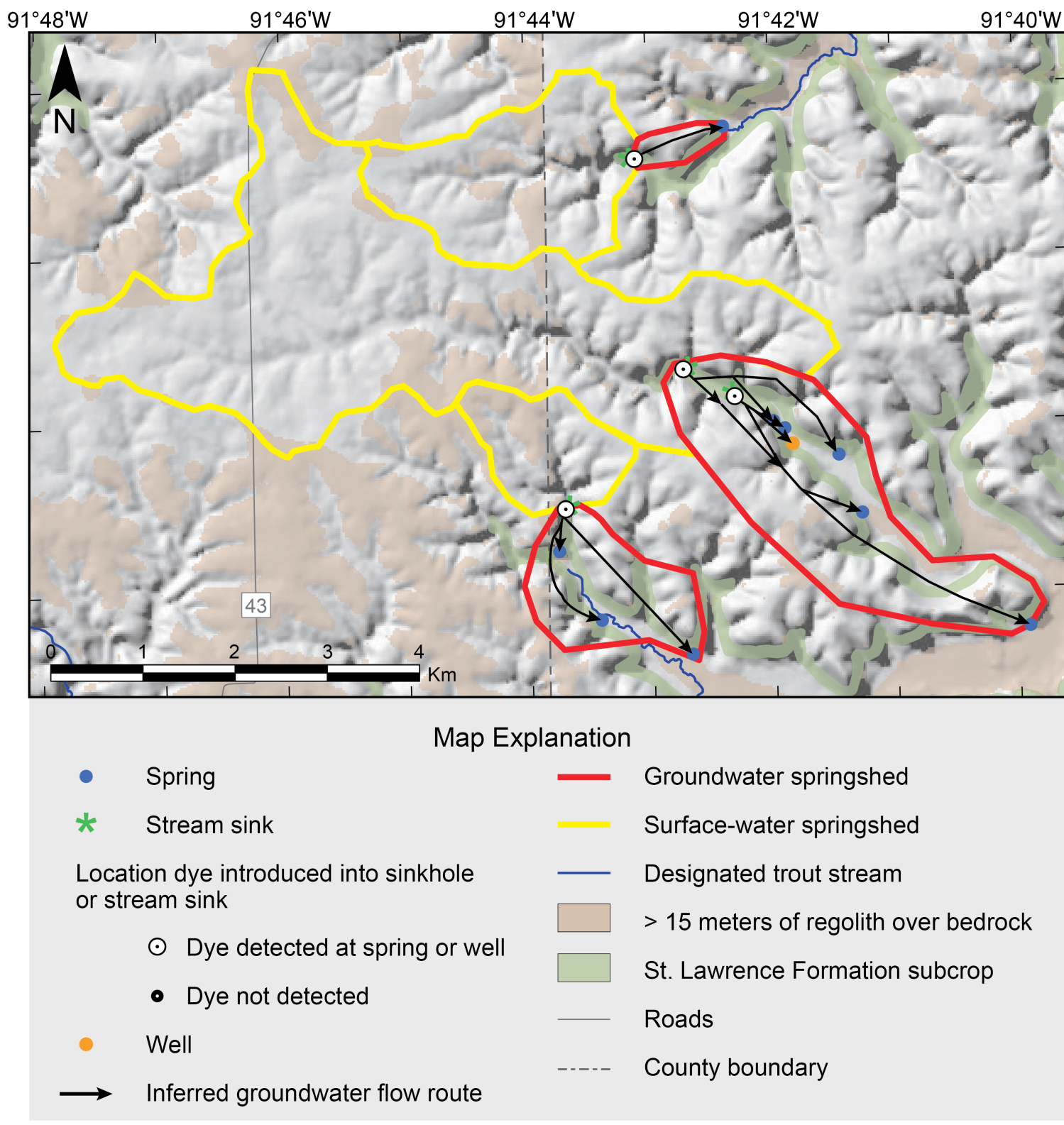

$43^{\circ} 44^{\prime} \mathrm{N}$

$43^{\circ} 42^{\prime} \mathrm{N}$

Figure 6. Map of Springsheds in the St. Lawrence and Lone Rock pseudokarst, (Inset 4 from Green and Alexander, 2014). The vertical dashed line is the Fillmore County/Houston County boundary. The streams in the Surface Water Springsheds are perennial that sink into stream sinks in the St. Lawrence Formation. Dye traces from these stream sinks have been detected at St. Lawrence and Lone Rock Formation springs. The Groundwater Springsheds boundaries are based on the dye traces and on field observations that indicate the hillsides along the valleys contribute water to the flow system.

tracing investigations in the St. Lawrence Formation have demonstrated breakthrough travel velocities of 90 to 600 meters per day (Green et al., 2008, 2012,). These are about an order of magnitude lower than the observed breakthrough travel velocities in the Galena limestone, the best-developed carbonate karst in Minnesota (Green et al., 2005). These velocities, however, are a few orders of magnitude faster than velocities expected for aquifers dominated by porous media flow, and many orders of magnitude faster than expected flow velocities of rocks mapped as aquitards. The breakthrough curves of the St. Lawrence traces rise rapidly to a peak and then fall with FWHMs of months. The dye has been consistently detected at springs for one to three years after it was 
released into a stream sink (Green et al., 2012). The St. Lawrence has few mapped sinkholes (one to three per county) and no known caves. Its primary features are stream sinks and springs. Surface-water springsheds that are thousands of hectares may drain into one set of stream sinks in a valley. Streams commonly sink into the upper St. Lawrence in valleys but the terminal sinking point often moves up and down the valley depending on stream stage. In these settings, the streams are a series of pools and riffles with the pools functioning as the stream sinks. In locations where the streams flow along bedrock exposures, the stream sinks are typically discrete points. There are also streams that lose flow but do not totally disappear as they cross the upper St. Lawrence. Dye tracing has demonstrated that most of the groundwater springsheds align with surface topography but there are examples where dye traces have crossed surface watershed divides. Multiple springs may be connected to single sinking points of streams in valleys.

The Lone Rock Formation, a fine siliciclastic unit, is the bedrock unit below the St. Lawrence. The Lone Rock is mostly composed of a fine-grained sandstone and siltstone with interbedded shale and dolostone (Mossler, 2008). Dye traces from St. Lawrence stream sinks at three sites in southeast Minnesota have been detected at Lone Rock springs (Barry et al., 2015). These traces have demonstrated that the Lone Rock also has a karstlike conduit flow component. Observed breakthrough travel velocities were between 21-214 meters/day using passive charcoal detectors and 314 meters/day using automatic water samplers; dye was still being detected over one year later at springs monitored from one of the tracing sites (Barry et al., 2015).

In Figure 6, the GwSs includes the area between the stream sink where dye was introduced into St. Lawrence, and the St. Lawrence or Lone Rock springs where it was detected. Our field observations and spring flow measurements of St. Lawrence and Lone Rock springs have shown that these springs respond rapidly (less than 24 hours) to large precipitation events, although they have no visible changes in turbidity or temperature (Green et al., 2014; Luhmann et al., 2011). We have interpreted these observations to mean that water is infiltrating into the hillsides above these springs; there it raises the pressure head in the bedrock units which increases spring discharge while not impacting spring turbidity. To account for these phenomena and the strong regional groundwater flow component, the
GwS boundaries are extended into the upland interfluves between the stream sinks and springs.

The lack of large conduit networks in outcrop and borehole observations makes classifying the St. Lawrence and Lone Rock as karst problematic. Flow characterization through dye tracing and breakthrough curves for these units is more consistent with their being classified as pseudokarst. Pseudokarst has been described as "landscapes with morphologies resembling karst, and/or may have a predominance of subsurface drainage through conduit type voids, but lack the element of long-term evolution by solution and physical erosion" (Kempe and Halliday, 1997).

Recent work in the siliciclastic bedrock of southeast Minnesota has found that millimeter-to-centimeter-sized, bedding-parallel apertures are connected through an anastomosing network of apertures, clustered along discrete $(<2 \mathrm{~m})$ stratigraphic intervals and are found at depths exceeding 200 meters (Runkel et al., 2015). The apertures are more limited in size than in karsted carbonate rock. They are commonly associated with distorted bedding which is interpreted to reflect dewatering features that occurred shortly after burial when the rock was only partially lithified. These voids, then, are unlikely to primarily be the result of solution as karst has been traditionally defined (Stewart et al., 2012; Runkel et al., 2015).

\section{Summary}

Springs are the discharge points for groundwater systems. Dye tracing to delineate springsheds has been an ongoing activity since the 1970s in southeast Minnesota. This tracing work has been compiled into a new map entitled, "Mapped Paleozoic Bedrock Springsheds in Southeast Minnesota" (Green and Alexander, 2014). This map displays both delineated groundwater and surface water springsheds in carbonate karst bedrock formations, and also in pseudokarst bedrock formations. The map is available on the Minnesota Department of Natural Resources website.

These dye traces collectively demonstrate that in southeast Minnesota:

1. Springs are the outlets of conduit flow systems.

2. Conduit flow dominates groundwater transport in these carbonate and siliciclastic bed rock aquifers independent of the presence or absence of surface karst features. 
3. The springsheds of these springs have three components: Groundwater springsheds (analogous to classic karst autogenic recharge areas), surface water springsheds (analogous to classic karst allogenic surface runoff areas) and regional groundwater springsheds.

4. Surface water springsheds can be up to several orders-of-magnitude larger than the groundwater springsheds to which they contribute water. A surface water springshed can feed surface flow into one or several stream sinks. Those multiple stream sinks may be in one or more groundwater springsheds.

5. Breakthrough curves typically show groundwater flow velocities in the hundred-of-meters to kilometers per day range in all of the bedrock aquifers tested.

6. The widths and tails of breakthrough curves in these conduit flow systems vary with the bedrock aquifers. The breakthrough curves of Galena Group have FWHMs of a few hours and tails that are down to background in a few days. Breakthrough curves of the Prairie du Chien Group in the Duschee Creek Springshed also have FWHMs of hours but have tails that continue for weeks. St. Lawrence and Lone Rock Formations breakthrough curves have FWHMs of months to years.

\section{Acknowledgements}

The authors gratefully acknowledge very constructive critical reviews of this paper by Chris Smart and two anonymous reviewers. We also acknowledge and thank hundreds of colleagues, co-workers, students, friends and land owners who have participated in the dye traces over the decades.

Partial funding for this project was provided by the Minnesota Environment and Natural Resources Trust Fund as recommended by the Legislative-Citizen Commission on Minnesota Resources (LCCMR) and its predecessors. Special thanks are given to Holly Johnson of the DNR for her graphic editing assistance, Ruth MacDonald of the DNR, and Betty Wheeler of the University of Minnesota for their thorough editing of the manuscript.

\section{References}

Alexander EC Jr, Green JA, Alexander SC, Spong RC. 1996. Springsheds, Plate 9, Geologic Atlas of Fillmore County, Minnesota: Part B, County Atlas
Series C-8, Minnesota Department of Natural Resources, St. Paul, MN. http://www.dnr.state. mn.us/waters/programs/gw section/mapping/ platesum/fillcga.html.

Alexander EC Jr, Huberty BJ, Anderson KJ. 1991. Olmsted County Dye Trace Investigation - Final Report. Report to Olmsted County prepared by Donohue and Associates, February 1991, 7 loose leaf binders.

Alexander EC Jr., Milske JA. 1986. Dye tracing studies of the Fountain Minnesota Sewage System. Proceedings of the Environmental Problems in Karst Terranes and Their Solutions Conference, National Water Well Associations, Dublin, Ohio, p. 249-262.

Alexander EC Jr, Runkel AC, Tipping RG, Green JA. 2013. Deep time origins of sinkhole collapse failures in sewage lagoons in SE Minnesota. In: Land L, Doctor DH. Stephenson JB, (editors) NCKRI Symposium 2 Proceedings of the 13th Multidisciplinary Conference on Sinkholes and the Engineering and Environmental Impacts of Karst, Carlsbad, New Mexico, published on-line by NCKRI, Carlsbad, NM, p. 285-292. ISBN 9780-9795422-7-5

Alexander SC. 2005. Spectral deconvolution and quantification of natural organic material and fluorescent tracer dyes. In: Beck B, (editor), Sinkholes and the Engineering and Environmental Impacts of Karst: Proceedings of the Tenth Multidisciplinary Conference, San Antonio, 24-28 September 2005, ASCE Geotechnical Special Publication 144, Amer. Soc. Civil Engineers, Reston, VA, p. 441-448. http://dx.doi. org/10.1061/40796(177)47.

Barry JD, Green JA, Steenberg JR. 2015. Conduit flow in the Cambrian Lone Rock Formation, Southeast Minnesota, U.S.A. These proceedings, $12 \mathrm{p}$.

Copeland, RE. 2003. Florida spring classification system and spring glossary. Florida Geological Survey: Special Publication 52, $17 \mathrm{p}$.

Green JA, Alexander EC Jr. 2011. Dye tracing observations from the Prairie du Chien Group in Minnesota: 2011 Geological Society of America meeting, Abstracts with Programs, Abstract 60-11 43 (5): 167.

Green JA, Alexander EC Jr. 2014. Mapped Paleozoic Karst Springsheds in Southeast Minnesota. Minn. Dept. Natural Res., St. Paul, MN. Pdf available from: http://files.dnr.state.mn.us/waters/ groundwater_section/mapping/springshed/ springshed map.pdf.

Green JA, Alexander SC, Alexander EC Jr. 2005. Springshed mapping in support of watershed management. In: Beck B, (editor). Sinkholes and the Engineering and Environmental Impacts of Karst: Proceedings of the Tenth Multidisciplinary 
Conference, San Antonio, 24-28 September 2005, ASCE Geotechnical Special Publication 144, Amer. Soc. Civil Engineers, Reston, VA, 403-409.

Green JA, Barry JD, Alexander, EC Jr. 2014. Springshed Assessment Methods for Paleozoic Bedrock Springs of Southeastern Minnesota. Report to the Legislative-Citizen Commission on Minnesota Resources. Minn. Dept. Natural Resources, St. Paul, MN, 48 p. Available from: http://files.dnr.state.mn.us/waters/groundwater section/mapping/springshed/springshed assessment protocols.pdf.

Green JA, Luhmann AJ, Peters AJ, Runkel AC, Alexander EC Jr, Alexander SC. 2008. Dye tracing within the St. Lawrence confining unit in southeastern Minnesota In: Yuhr LB, Alexander EC Jr, Beck BF (editors). Sinkholes and the engineering and environmental impacts of karst: American Society of Civil Engineers, Proceedings ASCE GSP 183: 477-484. http://dx.doi. org/10.1061/41003(327)45.

Green JA, Runkel AC, Alexander EC Jr. 2012. Karst conduit flow in the Cambrian St. Lawrence confining unit, southeast Minnesota, USA: Carbonates and Evaporites 27 (2): 167-172. http:// dx.doi.org/10.1007/s13146-012-0102-9.

Hallberg GR, Libra RD, Bettis EA III, Hoyer BE. 1983. Hydrogeologic and water quality investigations in the Big Spring Basin, Clayton County, Iowa. Iowa Geological Survey, Open-file Report 84-4, 321 p.

Kalmes A, Mohring E. 1995. Sinkhole treatment to improve water quality and control erosion in southeastern Minnesota. In: Beck BF, Pearson, FM, (editors). Karst Geohazards, Proceedings of the fifth multidisciplinary conference on sinkholes and the engineering and environmental impact of karst, Gatlinburg, TN, 2-5 April 1995: 265-272.

Kempe S, Halliday WR. 1997. Report on the discussion on pseudokarst, in Proceedings of the 12th International Congress of Speleology, v. 6, Basel, Switzerland, Speleoprojects.

Kingston SP. 1943. Contamination of water supplies in limestone formation. J. Amer Water Works Assoc 35: 1450-1456.

Luhmann AJ, Covington MD, Alexander SC, Chai SY, Schwartz BF, Groten JT, Alexander EC Jr. 2012 Comparing conservative and nonconservative tracers in karst and using them to estimate flow path geometry. Journal of Hydrology 448-449: 201-211. http://dx.doi.org/10.1016/j. jhydrol.2012.04.044.

Luhmann AJ, Covington MD, Peters AJ, Alexander SC, Anger CT, Green JA, Runkel AC, Alexander EC, Jr, 2011, Classification of thermal patterns at karst springs and cave streams: Groundwater 49 (3): 324-335. http://dx.doi.org/10.1111/j.1745- 6584.2010.00737.x.

Minnesota Department of Natural Resources, 2014, National Hydrography Dataset (NHD) - HighResolution - Minnesota: last accessed August, 2014 at https://gisdata.mn.gov/dataset/waternational-hydrography-data.

Mohring E, Alexander E. 1986 Quantitative tracing of karst groundwater flow: Southeastern Minnesota, North Central, U.S.A. Proceedings of the 5th International Symposium on Underground Water Tracing, Athens, Instit. of Geol. and Mineral Expl., Athens, Greece, p. 215-227.

Mossler JH. 2008. Paleozoic stratigraphic nomenclature for Minnesota: Minnesota Geological Survey Report of Investigations 65: 76 p., 1 pl. http://purl. umn.edu/58940.

Runkel AC, Cowan CA, Stewart ZW, Jacobson WZ. 2015, A Possible Origin of Hydraulically Significant Bed Parallel Macropore Networks in Siliciclastic Bedrock: Geological Society of America Program 47 (5): 55. http:// www.geosociety.org/Sections $/ \mathrm{nc} / 2015 \mathrm{mtg} /$ documents/2015 NC program.pdf.

Runkel AC, Steenberg JR, Tipping RG, Retzler AJ. 2014. Geologic controls on groundwater and surface water flow in southeastern Minnesota and its impact on nitrate concentrations in streams: Minnesota Geological Survey Open File Report 14-02: 154p. http://conservancy.umn.edu/ handle/11299/162612.

Runkel AC, Tipping RG, Alexander EC Jr, Green JA, Mossler JH, Alexander SC. 2003. Hydrogeology of the Paleozoic bedrock in southeastern Minnesota: Minnesota Geological Survey, Report of Investigations 61: 105 p., 1 map in pocket. http://purl.umn.edu/58813.

Stewart ZW, Cowan CA, Runkel AC. 2012. Sediment deformation in the Jordan Sandstone and influences on modern hydrogeology: Geological Society of America Abstracts with Programs. 44 (7): 556. https://gsa.confex.com/gsa/2012AM/ finalprogram/abstract_209806.htm.

Wheeler BJ. 1983. Groundwater Tracing in the Duschee Creek Karst Basin in Southeast Minnesota. Plan B MSc Paper, Geology \& Geophysics Dept., Univ. of Minn., Minneapolis. 74 p. 